\title{
TRADISI PEMINANGAN DAN WALIMMAT AL-'URS MASYARAKAT MUSLIM SUKU MARIND PAPUA KABUPATEN MERAUKE PERSPEKTIF AKULTURASI BUDAYA
}

\author{
Amri \\ Institut Agama Islam Negeri Fattahul Muluk Papua \\ Email: amrigede91@gmail.com \\ DOI: 10.37876/adhki.v2i1.36
}

\begin{abstract}
The culture of the Marind tribe of Papua has been preserved for a long time to be preserved until today. like the traditional culture of Marind in the tradition of marriage and wedding parties. The Marind people believe in Islam as their religion. so there is an acculturation process in displaying the practice of the tradition. For this reason, this study will examine the tradition of marriage and walimat al-'urs, the Muslim community of the Marind Tribe of Papua in a review of cultural acculturation. Qualitative research is used during the research process. In-depth observations and interviews were applied during data collection. This research shows that the Muslim community of the Marind Tribe of Papua in its implementation still uses the traditions of the past because they respect the customs and minority Islam in the family, practice mixed traditions between the two cultures, and eliminate traditions. While the process of cultural acculturation experienced by the people of the Marind tribe of Papua to the tradition of marriage and marriage parties. So that emerged a new tradition of the Marind Muslim community. This research also results that the Muslim community of Marind tribe upholds the customs that prioritize the appreciation and practice with the content of customary values, but on the other hand also fulfills all matters relating to sharia in Islamic culture. The occurrence of cultural contact meetings between Marind and religious customs, according to this study does not indicate a process of rejection.
\end{abstract}

Keywords: Peminangan, walimat al-'urs, marind tribe, cultural acculturation

\begin{abstract}
Abstrak
Budaya Suku Marind Papua dipelihara sejak dahulu untuk dilestarikan hingga saat ini. seperti budaya adat Marind dalam tradisi peminangan dan pesta perkawinannya. Masyarakat Suku Marind meyakini agama Islam sebagai agama bagi mereka. sehingga ada proses akulturasi dalam menampilkan praktik tradisi tersebut. Untuk itu, penelitian ini akan mengkaji tradisi peminangan dan walimat al-'urs masyarakat muslim Suku Marind Papua dalam tinjauan akulturasi budaya. Penelitian kualitatif digunakan selama proses penelitian. Observasi dan wawancara mendalam diterapkan selama pengumpulan data. Penelitian ini menunjukan bahwa masyarakat muslim Suku Marind Papua dalam pelaksanaannya masih menggunakan tradisi masa lalu karena menghargai adat dan Islam minoritas dalam keluarga, pelaksanaan tradisi campuran antara kedua budaya, dan menghilangkan tradisi. Sedangkan terjadinya proses akulturasi budaya dialami oleh masyarakat Suku Marind Papua terhadap tradisi peminangan dan pesta pekawinan. Sehingga muncul tradisi baru masyarakat Muslim Suku Marind. Penelitian ini juga menghasilkan bahwa masyarakat Muslim Suku Marind memegang teguh adat istiadat yang mengedepankan penghayatan dan pengamalan dengan muatan nilai berunsur adat, namun disisi lain juga memenuhi semua urusan yang berkenaan dengan syariat dalam budaya Islam. Terjadinya pertemuan kontak budaya antara adat Marind dan agama, sesuai penelitian ini tidak menunjukan proses penolakan.
\end{abstract}

Kata Kunci: Peminangan, walimmat al-'urs, suku marind, akulturasi budaya 


\section{Pendahuluan}

Masalah perkawinan sudah diatur dalam tatatanan hukum di Indonesia. Perkawinan menurut perundangan ialah ikatan lahir batin antara seorang pria dengan seorang wanita sebagai suami istri dengan tujuan membentuk keluarga (rumah tangga) yang bahagia dan kekal berdasarkan Ketuhanan yang Maha Esa. ${ }^{1}$ Sedangkan menurut hukum adat pada umumnya di Indonesia perkawinan itu bukan saja berarti sebagai perikatan perdata, tetapi juga merupakan perikatan adat dan sekaligus merupakan perikatan kekerabatan. Jadi terjadinya suatu ikatan perkawianan bukan semata-mata membawa akibat terhadap hubungan-hubungan keperdataan seperti hak dan kewajiban orang tua, tetapi juga menyangkut hubungan-hubungan adat istiadat kewarisan, kekeluargaan, kekerabatan serta menyangkut upacara-upacara adat dan keagamaan. ${ }^{2}$

Perkawinan juga tidak terlepas dari konsep sebuah tradisi atau adat. Yaitu sebuah konsep yang substansi dan isi semua yang kita warisi dari masa lalu, semua yang disalurkan kepada kita melalui proses sejarah, merupakan warisan sosial. Mengenai tradisi, hubungan antara masa lalu dan masa kini haruslah lebih dekat. Tradisi mencakup kelangsungan masa lalu dimasa kini ketimbang sekedar menunjukan fakta bahwa masa kini berasal dari masa lalu. ${ }^{3}$

Kemudian dalam perkawinan dikenal dengan peminangan dan walimat al-'urs. Adat tradisi dalam peminangan Suku Marind yang sudah turun temurun dilakukan oleh warga masyarakat sekitar bermacam-macam, yaitu tradisi yang biasa mereka sebut "Masuk Minta". Masuk minta ini biasa dimulai dari pembayaran uang susu buat orang tua dari pihak laki-laki kepada pihak perempuan. Uang susu itu bukan Cuma uang susu saja, melainkan biasaya ada syarat lain. Contohnya, dari pihak perempuan minta berapa banyak uang susunya. Kemudian ada yang namanya "Wati" yaitu sejenis minuman yang memabukan, bentuknya seperti batang daun sirih, kemudian ada "Sopi" sopi itu fermentasi dari nira kelapa terus harus ada pinang, sirih dan Kapur sebagai perlengkapan peminangan.

Sedangkan dalam adat masyarakat asli Papua setiap pesta perkawinan atau walimat al-'urs sebagaimana pesta lainya selalu mengedepankan nilai-nilai khas adat suku mereka diantaranya makanan, pakaian dan simbol-simbol yang harus dilestarikan sampai saat ini. Kemudian ada beberapa ekor babi harus dipotong yang diperuntukan khusus untuk dimakan. Para kerabat biasanya berpesta, menyayi, makan minum sepuasnya selama acara perkawinan berlangsung, dan membagikan daging babi kepada kerabat sesuai adat kebiasaan yang berlaku. ${ }^{4}$

Kabupaten Merauke semakin tahun sudah berkembang pesat dan mulai mengikuti zaman modern. Bahkan Kabupaten Merauke menjadi salah satu kabupaten yang toleransi umat beragama sangat kuat. Maka dari itulah masyarakat Suku Marind

\footnotetext{
${ }^{1}$ Hilman Hadikusuma, Hukum Perkawinan Indonesia Menurut; perundangan, Hukum Adat, Hukum Agama, (Bandung: CV.Mandar Maju, 2007) hlm.5

${ }^{2}$ Hilman Hadikusuma, Hukum Perkawinan Indonesia Menurut; perundangan, Hukum Adat, Hukum Agama,.....hlm. 8

${ }^{3}$ PiÖtr, Sztompka, Sosiologi Perubahan Sosial, (Terj.Alimandan), (Jakarta: Prenada Media Grup, 2007) hlm. 69

${ }^{4}$ Ibu Ilde Fonsia Mahuze, Wawancara, Merauke, tanggal 22 Maret 2017
} 
sudah mengenal Islam dan lambat laun menjadi muallaf dan beradapatasi dengan umat Islam lainya. Walaupun hanya seberapa orang yang masuk Islam namun kebudayaankebudayaan masa lalu masih erat dalam kehidupan mereka.

Dari latar belakang tersebut, lantas bagaimana masyarakat Suku Marind beradaptasi dari adat masa lalu dengan setelah mereka beradaptasi dalam masyarakat Islam atau menjadi muallaf. Artinya budaya-budaya pernikahan mereka dapat dipakai setelah mereka beradaptasi dengan masyarakat Islam atau muallaf. Penulis juga mencoba mengetahui budaya-budaya atau tradisi mereka yang turun temurun dilakukan dan setelah adanya kontak terhadap masyarakat muslim atau muallaf, dalam konteks proses peminangan dan walìmat al-'urs yang dilakukan masyarakat Suku Marind di Kabupaten Merauke ditinjau melalui pendekatan akulturasi budaya.

\section{Metode Penelitian}

Jenis penelitian yang digunakan dalam penelitian ini adalah penelitian emperis atau studi kasus. Studi kasus adalah penelitian yang dilakukan secara intensif, terici dan mendalam terhadap suatu organisasi, lembaga atau gejala tertentu. ${ }^{5}$ Yang pada penelitian ini, penelitian ditunjukan kepada para pelaku tradisi Peminangan dan walimat al-'urs Muslim Suku Marind Papua di Kabupaten Merauke .

Dalam penelitian ini juga peneliti menggunakan penelitian kualitatif, penelitian kualitatif adalah sebuah penelitian yang menghasilkan data-data berupa kata tertulis maupun lisan dari orang dan perilaku yang diamati oleh peneliti. ${ }^{6}$ Penelitian ini ditinjau berdasarkan pengumpulan datanya (tempatnya), maka jenis penilitian ini adalah penelitian lapangan. ${ }^{7}$ Pendekatan penelitian yang digunakan dalam penelitian ini adalah deskriptif kualitatif. Dalam penelitian ini, peneliti menggali tentang tradisitradisi peminangan dan walimat al-'urs masyarakat muslim Suku Marind Papua Kabupaten Merauke. Sumber data diperoleh melalui metode observasi, wawancara dan dokumentasi. Setelah data ditemukan dan telah terkumpul maka selanjutnya dianalisis dengan menggunakan akulturasi budaya.

\section{Tradisi Peminangan dan Walìmat al-'urs Muslim Suku Marind Papua}

Suku Marind adalah suku yang berada di Kabupaten Merauke. Suku Marind ini juga biasa disebut orang Marind Anim yang hidup di daerah pedalaman Merauke seperti Buraka dan Bian, daerah ini merupakan dataran rendah bersavana dengan floranya yang mirip flora Australia dan datarannya berawa-rawa yang ditumbuhi pohon sagu disungai-sungai. ${ }^{8}$

Suku Marind Anim di Kabupaten Merauke cenderung tempat tinggalnya di

\footnotetext{
${ }^{5}$ Suharsimi Arikunto, Prosedur Penelitian: Suatu Pendekatan Praktik, (Jakarta: Bineka Cipta, 2010) Hlm.81

${ }^{6}$ Lexy J. Moleong, Metodologi Penelitian Kualitatif, (Bandung: Rosda Karya, 2005) hlm.4

7 Moh. Kasiran, Metodologi Penelitian: Refleksi Pengembangan Pemahaman dan Penguasaan Metode Penelitian, (Malang: UIN Press, 2010) hlm.11

${ }^{8}$ Aryanto Ali, Dokumen Materi Kuliah: Etnografi Papua,............hlm. 4
} 
bagian pinggiran, seperti Kelurahan Samkai dan Kelurahan Kamahedoga ${ }^{9}$ Distrik Merauke yang paling dominan sebagai tempat tinggal, karena daerah tersebut dekat dengan pantai dan sungai. Dan setiap kelurahan selalu ada ketua adat ( kepala suku ). Mereka selalu menghoramati kepala suku tersebut. Apa yang kepala suku perintahkan pasti mereka selalu menaati dan melakukannya.

Tradisi peminangan dan pesta perkawinan dalam (Adat Marind) suku mereka sudah dilakukan sejak turun temurun hingga nenek moyang mereka. Dan setiap suku mereka harus wajib melaksanakan adatnya. Bahkan setiap orang dari suku mereka melanggar atau tidak melakukan ritual adatnya harus mengakui kesalahan dan harus diselesaikan di lembaga adat. Dan apabila terbukti melanggar adat maka orang tersebut dapat diberikan sanksi. Sanksi itu dapat berupa uang dan pemberian beberapa ekor babi, dan lain sebagainya.

Suku Marind atau orang asli Papua ini yang bermukim di Kabupaten Merauke juga menggunakan istilah bahwa laki-laki adalah raja, artinya bahwa perempuan harus mengikuti apa yang laki-laki ingin lakukan. Dalam masalah adat mereka pun digunakan istilah ini, jadi setiap perempuan yang ingin melakukan sebuah ritual atau prosesi adat harus mengikuti apa kehendak laki-laki. Pernikahan campuran pun juga dilakukan hal ini, apabila seorang perempuan pendatang atau dari suku lain mereka tetap harus mengikuti adat dari laki-laki tersebut. Namun sebelum melaksanakan adat biasanya antara kedua belah pihak melakukan musyawarah terlebih terdahulu. ${ }^{10}$

Masalah adat peminangan dan pesta perkawinan Suku Papua ini atau yang biasa kenal dengan adat Marind, tidak sesulit atau sebanyak yang orang pikirkan. Karena adat perkawinan mereka hanya terfokus terhadap pemberian dan syarat adat saja, dan syarat tersebut tidak menyusahkan dari pihak mempelai laki-laki dan pesta perkawinannya pun sangat sederhana bahkan mudah.

Islam sendiri adalah agama bagi mereka setelah Kristen dan Katolik, Populasi masyarakat Muslim di Papua cukup besar. Kabupaten Merauke, contohnya, masyarakat muslim cukup besar. ${ }^{11}$ Dalam hal tradisi suku Marind orang yang beragama Kristen dan Khatolik lebih aktif menggunakan tradisi masa lalu dari nenek moyang mereka hingga saat ini, dibandingkan dengan mereka yang sudah berbaur dengan budaya Islam.

Berdasarkan hasil analisa dari pengumpulan keseluruhan data didapatkan tradisi-tradisi peminangan dan walìmat al-'urs Muslim Suku Marind Papua Kabupaten Merauke. Adapun pelaksanaannya di lakukan tiga cara, Pertama; tradisi tradisional (masa lalu) karena menghargai tradisi adat Marind dan akibat Islam minoritas dalam keluarga, kedua; tradisi percampuran antara kedua budaya, dan ketiga; tradisi yang menghilangkan tradisi adat Marind ( Modern ).

Sekian banyak informan dan kasus-kasus menyatakan dalam masalah adat turun temurun dalam tradisi peminangan Suku Marind Papua diperlihatkan peryataan

${ }^{9}$ Kelurahan Samkai dan Kelurahan Kamahedoga adalah salah satu kelurahan yang berada di Distrik/Kecamatan Merauke, Kabupaten Merauke. Kelurahan ini letak geografisnya terletak dipingiran Sungai atau Laut, kelurahan ini sebagai penyumbang masyarakat Suku Marind terbanyak

${ }^{10}$ Observasi di Kantor Lembaga Masyarakat Adat ( LMA ) Marind Mbuti Kabupaten Merauke, pada tanggal 22 Juli 2017

${ }^{11}$ Sumber Online, Merauke, Tempat Mayoritas Muslim Penduduk Papua, INTERNASNEWS, diakses 28 Juni 2017. 
yang bebeda-beda. Jadi hal ini membuktikan bahwa tradisi peminangan yang mereka lakukan selama turun-temurun masih dilakukan. Namun lebih banyak perbedaan antara budaya turun temurun dengan setelah mereka beradaptasi dengan Islam.

Walaupun kenyataannya tradisi lokal masih dilakukan, namun ternyata banyak juga Muslim Suku Marind Papua Kabupaten Merauke sama sekali tidak melakukanya, dengan alasan bukan tidak menghargai tradisi budaya mereka, tetapi karena sebelumnya sudah ada musyawarah antara semua komponen keluarga dari pihak lakilaki dan perempuan untuk menyepakati tradisi yang dipakai. Kemudian alasan karena akibat ekonomi yang membuat tradisi itu tidak dilakukan diganti dengan tradisi sederhana.

Dalam masalah tradisi walìmat al'urs ini tidak ada yang unik atau tradisi khusus yang dilakukan oleh Muslim Suku Marind Papua di Kabupaten Merauke. Dalam adat mereka mayoritas lebih menggunakan tradisi modern yaitu tradisi-tradisi masyarakat muslim pergunakan. Kemudian tradisi-tradisi Islam seperti khataman Quran, yasin dan tahlil dilakukan untuk pelengkap syukuran pesta pernikahan. Namun di lain sisi juga kesamaan-kesamaan pun ada, hal itu terjadi karena banyak faktor yang mempengaruhinya.

Terlepas dari tradisi peminangan dan walìmat al-'urs masyarakat suku Marind Muslim di Kabupaten Merauke yang merupakan peneladaanan leluhur dan nenek moyang mereka secara turun-temurun. Dalam upacara yang dilakukan oleh masyarakat ini dilakukan dengan dua cara. Yang pertama upacara tradisional yang dilakukan adat setempat yaitu adat Marind. Kedua, dilakukan menggunakan upacara modern yaitu upacara yang dilakukan dengan aturan Islam. Kemudian adakalanya para pelaku tradisi peminangan dan walimmat al-'urs menggunakan kedua cara tersebut.

Dalam melaksanakan peminangan dan walimmat al-'urs, Islam tidak memberikan tata cara yang baku, namun dipasrahkan pada adat dan kebiasaaan yang berlaku dalam masyarakat. Berangkat dari kelonggaran ini, maka dalam tata cara khitbah dan walimat al-'urs masyarakat mengikuti tata cara adat yang telah lama ada dalam kehidupan mereka. Jika ditinjau dari sudat pandang Islam, Alquran sebagai pedoman hidup telah menjelaskan bagaimana kedudukan tradisi (adat-istiadat) dalam agama itu sendiri. Karena nilai-nilai yang temaktub dalam sebuah tradisi dipercaya dapat mengantarkan keberuntungan, kesuksesan, kelimpahan dan keberhasilan dalam masyarakat tersebut. ${ }^{12}$

Penyelenggaraan khitbah atau peminangan dalam pandangan masyarakat Muslim Suku Marind Papua peneliti melihat sebagaimana yang sudah umum berlaku ditengah-tengah masyarakat untuk dilaksanakan dengan tujuan berjanjian dalam sebuah perkawinan. Menurut mereka janji dalam peminangan harus ditepati dan meninggalkanya adalah perbuatan tercela. Adapun syarat peminangan untuk komunitas Suku Marind Papua diutamakan harus memperhatikan status orang yang akan dipinang dan status kekeluargaan, kemudian dalam masalah mengetahui keadaan jasmani, akhlak serta keadaan-keadaan lainya yang dimiliki oleh perempuan yang akan dipinang. Sedangkan masalah keilmuan serta status sosial dan kekayaan hanyalah

${ }^{12}$ Ardiun Hindi, Tradisi Bergubalan Dalam Perkawinan Masyarakat Muara Enim Sumatera Selatan Menurut Perspektif Islam, (Fakultas Syari'ah UIN Maliki Malang, Jurnal Hukum dan Syari'ah, Volume 1, No.1, 2010) hlm.1-2 
formalitas. Tata cara peminangan selalu mengedepankan laki-laki untuk menyampaikan secara langsung ke wali yang akan dipinang, apabila tidak ada wali maka persetujuan langsung dari perempuan.

Penyelenggaraan walimat al-'urs atau pesta perkawinan Muslim Suku Marind di Kabupaten Merauke juga dilakukan pada waktu ketika akad atau setelahnya. Tujuan walimmat al-'urs bagi mereka adalah sebagai tanda resminya adanya akad nikah sebagai tanda memulainya hidup baru bagi suami istri. Kemudian hal yang sangat penting dalam penyelenggaraan walimat al-'urs ini selain sebagai tanda akad nikah adalah mengumpulkan dengan rukun seluruh sanak keluarga mulai yang jauh hingga dekat, kemudian keluarga yang muslim dan non muslim serta sesama suku untuk mendoakan kedua pasangan. Dalam Islam diajarkan untuk sederhana dalam segala aspek kehidupan, termasuk dalam melaksanakan walimat al-'urs harus sederhana tidak boleh berlebih-lebihan. Dasar ini lah masyarakat Muslim Suku Marind Papua di Kabupaten Merauke dari segi aspek ekonomi rendah untuk tidak melaksanakan walimat al-urs secara meriah. Dibandingkan dengan komunitas mereka yang dari segi ekonomi mampu.

Eksistensi budaya Suku Marind sudah ada sebelum datangnya budaya Islam. Sehingga kultur yang tidak diatur sama sekali oleh ketentuan syariat sama sekali tidak ditinggalkan. Ataupun prinsip-prinsip ajaran Islam menjadi dasar dalam langgengnya pelaksanaan adat. Maka, proses pengamatan dan wawancara mengidentifikasi setidaknya ada beberapa hal yang sarat dengan muatan adat Suku Marind Papua dan Islam dalam Praktik kehidupan Masyarakat Muslim Suku Marind Papua di Kabupaten Merauke. Tradisi tersebut adalah dalam praktek seserahan peminangan, pakaian adat, makanan khas, prosesi walimat al-'urs. Dalam pelaksanaan perubahan-perubahan yang terjadi dalam pertemuan budaya suku marind setelah beradaptasi atau mengalami pertemuan kontak dengan budaya Islam ini dapat dilihat dalam tabel dibawah ini:

\section{Perubahan - Perubahan Tradisi Peminangan Suku Marind Papua Kabupaten Merauke Setelah Beradaptasi Dengan Budaya Islam}

\begin{tabular}{|c|c|c|c|c|c|}
\hline No & $\begin{array}{l}\text { Jenis Tradisi } \\
\text { Peminangan }\end{array}$ & Dipakai & Dihapus & Diganti & Keterangan \\
\hline 1. & $\begin{array}{l}\text { Datang } \\
\text { memakai } \\
\text { Pakaian adat, } \\
\text { tarian adat, } \\
\text { aksesoris adat, } \\
\text { bersama sanak } \\
\text { keluarga. }\end{array}$ & $\checkmark$ & - & $\checkmark$ & $\begin{array}{l}\text { Untuk pakaian adatnya } \\
\text { diganti lebih ke modern } \\
\text { (tertutup) dan ada yang } \\
\text { diganti dengan pakaian } \\
\text { modern }\end{array}$ \\
\hline 2. & $\begin{array}{l}\text { Membawa } \\
\text { tumbuhan atau } \\
\text { pohon wati, } \\
\text { sebagai mahar } \\
\text { mereka }\end{array}$ & $\checkmark$ & - & $\checkmark$ & $\begin{array}{l}\text { Diganti atau ditambah } \\
\text { seperangkat alat sholat } \\
\text { serta pakaian muslim, dan } \\
\text { lain-lain }\end{array}$ \\
\hline 3. & Babi peliharaan & $\checkmark$ & - & $\checkmark$ & Diganti dengan makanan \\
\hline
\end{tabular}




\begin{tabular}{|c|c|c|c|c|c|}
\hline & $\begin{array}{l}\text { minimal } 2 \text { ekor } \\
\text { sebagai serahan } \\
\text { atau mas kawin }\end{array}$ & & & & $\begin{array}{l}\text { yang halal, seperti: buah- } \\
\text { buahan, kue, dan lain-lain }\end{array}$ \\
\hline 5. & $\begin{array}{l}\text { Menyerahkan } \\
\text { serahan hasil } \\
\text { kebun yang } \\
\text { seperti: pisang, } \\
\text { tebu, singkong, } \\
\text { keladi, ubi jalar } \\
\text { (petatas). }\end{array}$ & $\checkmark$ & & $\checkmark$ & $\begin{array}{l}\text { Para pelaku yang } \\
\text { menghapus adat tersebut } \\
\text { biasanya menggantinya } \\
\text { dengan ke adat modern. }\end{array}$ \\
\hline 6. & $\begin{array}{l}\text { Menyerahkan } \\
\text { pakaian adat } \\
\text { Papua sebagai } \\
\text { mas kawin, } \\
\text { serta aksesoris } \\
\text { adat lainya } \\
\text { lainya. }\end{array}$ & $\checkmark$ & $\checkmark$ & $\checkmark$ & $\begin{array}{l}\text { mengganti dengan } \\
\text { pakaian modern atau } \\
\text { barang-barang dalam } \\
\text { tradisi modern }\end{array}$ \\
\hline 7. & $\begin{array}{l}\text { Pemberian } \\
\text { kapur dan sirih } \\
\text { pinang untuk } \\
\text { seserahan pada } \\
\text { saat } \\
\text { peminangan }\end{array}$ & $\checkmark$ & $\checkmark$ & - & \\
\hline 8. & $\begin{array}{l}\text { Pembayaran } \\
\text { Uang susu }\end{array}$ & $\checkmark$ & $\checkmark$ & $\checkmark$ & $\begin{array}{l}\text { Calon mempelai } \\
\text { perempuan adalah Suku } \\
\text { marind jadi tradisi ini } \\
\text { digunakan. Dan yang } \\
\text { mengganti. diganti dengan } \\
\text { mahar adat modern }\end{array}$ \\
\hline
\end{tabular}

Perubahan - perubahan Tradisi Pesta Perkawinan Suku Marind Papua di Kabupaten Merauke Setelah Beradaptasi Dengan Budaya Islam

\begin{tabular}{llllll}
\hline $\begin{array}{l}\text { No } \\
\cdot\end{array}$ & $\begin{array}{c}\text { Jenis Tradisi } \\
\text { Pesta } \\
\text { Perkawinan }\end{array}$ & Dipakai & Dihapus & Diganti & Keterangan \\
\hline 1. & Bakar Batu & $\checkmark$ & $\checkmark$ & $\checkmark$ & $\begin{array}{l}\text { Tradisi ini diganti } \\
\text { dengan khatam Al- } \\
\text { Quran, pembacaan yasin } \\
\text { tahlil atau syukuran }\end{array}$ \\
\hline 2. & $\begin{array}{l}\text { Makanan Babi, } \\
\text { tanaman wati }\end{array}$ & $\checkmark$ & $\checkmark$ & $\checkmark$ & $\begin{array}{l}\text { tradisi yang diganti } \\
\text { dengan makanan khas }\end{array}$ \\
\hline
\end{tabular}




\begin{tabular}{llll}
\hline & & & $\begin{array}{l}\text { suku Marind lainya, } \\
\text { sedangkan tradisi yang } \\
\text { dihapus memakai tradisi } \\
\text { moden }\end{array}$ \\
\hline 3. $\begin{array}{l}\text { Tempat } \\
\text { pernikahan } \\
\text { (musyawarah) }\end{array}$ & $\checkmark$ & - \\
\hline $\begin{array}{l}\text { Pakaian, tarian } \\
\text { adat }\end{array}$ & $\checkmark$ & $\checkmark$ & $\begin{array}{l}\text { Diganti dengan pakaian } \\
\text { modern, hiburan pada } \\
\text { umumnya }\end{array}$ \\
\hline 5. & $\begin{array}{l}\text { Tata ruang pesta } \\
\text { pernikahan }\end{array}$ & $\checkmark$ & $\begin{array}{l}\text { Diganti dengan tradisi } \\
\text { modern atau modifikasi } \\
\text { antara tradisional dan } \\
\text { modern }\end{array}$ \\
& & & \\
\hline
\end{tabular}

Dari gambaran tabel diatas dapat dapat disimpulkan bahwa tradisi yang dilakukan suku marind ( orang asli Papua di Kabupaten Merauke ) masih diterima oleh masyarakat Muslim Suku Marind ( orang asli Papua di Kabupaten Merauke ) sendiri. Sebagian besar tidak semua tradisi itu dipakai atau diterima kembali, namun tradisi banyak yang di hapus dan diganti. Kemudian alasan memakai tradisi kembali karena menganggap menghargai adat mereka dan unsur Islam minoritas dalam keluarga. Selain yang menerima tradisi turun temurun, ada juga yang menghapus atau mengganti semua tradisi itu dengan tradisi modern.

Beberapa pandangan tentang tradisi peminangan diatas, dapat dilihat bahwa masyarakat Muslim Papua sebagian besar masih menggunakan dengan berbagai faktor yang mereka ungkapkan. Sedangkan masalah tradisi walimat al-'urs atau pesta pernikahan, sebagian besar menghapus semua tradisi turun temurun dan menggantinya kedalam tradisi modern. Sebagian kecil masih menggunakan akibat banyaknya keluarga yang masih beragama Nasrani, dan juga ada yang melakukan tradisi itu sebagian kecil karena memang mereka mayoritas menikah di Kantor Urusan Agama setelah itu mengadakan pesta pernikahanya sederhana, hanya melakukan syukuran pernikahannya.

\section{Tinjauan Akulturasi Budaya}

Za'im Rais dalam desertasinya yang berjudul "The Minangkabau Traditionalists' Response to The Modernist Movement" mengatakan bahwa "dalam pertemuan dua budaya baru, memungkinkan terjadinya ketegangan. Sebagaimana respon kalangan tradisional dalam budaya Minang terhadap gerakan pembaharuan yang mengalami pergolakan. Bahkan sampai terjadi peperangan". ${ }^{13}$ Sheetal R. Shah mengatakan dalam tesisnya yang berjudul "The Impact of Acculturation and Religion on Intergenerational Family Conflict for Second Generation Asian Indian Americans", Southern Illinois University. Bahwa

13 Za'im Rais, The Minangkabau Traditionalists' Response to The Modernist Movement, Disertasi (Montreal: McGill University, 1994). 
dalam akulturasi yang berproses di generasi kedua keturunan India Amerika terjadi konflik diantara keluarga. ${ }^{14}$ Tetapi dalam penelitian ini kasus terjadinya kontak kedua kelompok budaya antara budaya Suku Marind Papua dan budaya Islam tidak mengalami ketegangan ataupun konflik. Kesatuan budaya Islam dan adat Marind dalam tradisi peminangan dan walimat al-'urs pada proses berikutnya melahirkan makna khusus yang berasal dari masa lalu dengan menyesuaikan kepada prinsip yang diterima keduanya. Pertemuan arus kebudayaan melahirkan model adaptasi yang berbeda, atau bahkan sama sekali baru dengan yang sudah ada sebelumnya, Model adaptasi ini menjadi bentuk akulturasi. Dengan proses akulturasi yang berjalan beriringan, maka dua arus kebudayaan yang bertemu melahirkan integrasi.

Masuknya Islam dengan membawa ajaran baru bagi kebudayaan Suku Marind kemudian mempengaruhi tradisi yang sudah ada. Maka, budaya Muslim Suku Marind Papua kemudian hadir dalam bentuk nilai dan standar yang baru pula sesuai dengan hasil pertemuan dua budaya. Keselelarasan dan sinkronisasi yang terjadi karena antara agama dan Budaya Suku Marind dapat digandengkan dengan terbentuknya pertimbangan para pelakunya. Kemudian digunakan untuk memaknai tradisi masa lalu dengan kehadiran Islam sebagai agama yang baru diterima.

Dalam masalah akulturasi Redfield menguraikan suatu proses akulturasi sebaiknya diperhatikan hal-hal sebagai berikut:

1. Bahan mengenai keadaan masyarakat penerima sebelum proses akulturasi dimulai, sebenarnya merupakan bahan tentang sejarah dari masyarakat bersangkutan. Dari uraian diatas bahwa kondisi masyarakat penerima sebelum proses akulturasi berjalan dalam hal ini Suku Marind Papua di Kabupaten Merauke percaya akan roh nenek moyang leluhur dan mengedepankan nilai - nilai leluhur mereka dan kepercayaan mitos - mitos, dongeng, legenda terdahulu. Dalam tradisi seserahan peminangan berupa simbol - simbol atau berupa barang seperti Babi, tanaman Wati serta hasil kebun itu adalah kehidupan lingkungan nenek moyang atau leluhur mereka terdahulu. Contohnya, tanaman Wati yang dikonsumsi oleh para leleluhur mereka dahulu fungsinya adalah untuk memperlancar atau sebagai penyemangat dalam bekerja, kemudian hewan babi dan hasil kebun seperti kelapa, sagu dan lain sebagainya adalah makanan disekitar lingkungan terdahulu.

2. Kepercayaan terhadap nenek moyang juga di jelaskan dalam Islam. Islam bertujuan membawa maslahat bagi manusia adalah menjauhkan diri dari kebiasaan-kebiasaan nenek moyang terdahulu yang bertentangan dalam Islam. Hal tersbut sebagaimana yang Allah firmankan surat Al-Baqarah : 170.

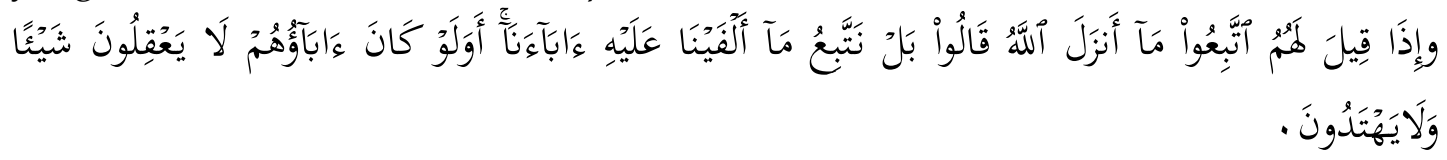

Artinya : dan apabila dikatakan kepada mereka "ikutilah apa yang telah diturunkan oleh Allah," mereka menjawab (tidak) kami menhikuti apa yang kami dapati pada nenek moyang

\footnotetext{
${ }^{14}$ Sheetal R. Shah, The Impact of Acculturation and Religion on Intergenerational Family Conflict for Second Generation Asian Indian Americans, Tesis (Carbondale: Southern Illinois University, 2006).
} 
kami (melakukanya)." Padahal, nenek moyang mereka itu tidak mengetahui apa pun dan tidak mendapat petunjuk..$^{15}$

Ayat tersebut menjelaskan kepada kita tentang orang-orang yang lebih patuh pada ajaran dan perintah nenek moyangnya dari pada syariat yang diwahyukan oleh Allah dalam Al-Quran. Seperti adanya kepercayaan-kepercayaan tertentu pada ritualritual yang menjanjikan keselamatan, ketenangan hidup, penolakan bala yang menjadi salah satu tradisi masyarakat Indonesia diberbagai daerah terutama masyarakat Suku Marind di Papua yang ritual/tradisi sangat bertentangan dengan Islam.

3. Individu-individu dari kebudayaan asing yang membawa unsur-unsur kebudayaan asing, dalam hal ini adalah agama Islam. Agama merupakan bagian dari setiap kebudayaan, dengan adanya budaya masyarakat akan dapat memahami yang terdapat pada dataran emperiknya atau agama yang tampil dalam bentuk formal yang menggejala dimasyarakat, perubahan kebudayaan dapat terjadi karena beberapa faktor yakni letak geografis daerah tersebut, sejarah dari generasi sebelumnya dan juga pengaruh dari bangsa lain. Namun perkembangan kebudayaan tidak dapat kita lepaskan dari agama.

Agama dan budaya keduanya memiliki hubungan yang sangat erat antara lain: agama merupakan bagian dari budaya, agama dapat melahirkan budaya agama terpisah dengan budaya. Agama memiliki beberapa fungsi sosial yang penting agama merupakan sanksi untuk perilaku yang luas dengan memberi pengertian tentang baik dan jahat, memberi contoh-contoh untuk perbuatan yang direstui serta memegang peranan penting dalam pemeliharaan solidaritas sosial. ${ }^{16}$

Kajian yang dilakukkan Ummi Sumbulah "Islam Jawa dan Akulturasi Budaya: Karakteristik, Variasi dan ketaatan Ekspresif" sampai kepada kesimpulan bahwa kemajemukan dan variasi agama yang terjadi pada masayarakat Jawa memberikan makna dan nuansa. Agama Jawa, yang dipandang penuh dengan campur aduk dengan kebudayaan lokal, simbolisme kultus, literalisme Islam, mistik dan bahkan Hinduisme. ${ }^{17}$

Kajian yang berbeda dengan penelitian ini dalam pertautan adat dan Islam Suku Marind Muslim Papua sebagaimana penelitian ini justru menunjukan karena ketiadaan agama yang dianut sebelum Nasrani datang kecuali kalau anemisme dianggap sebagai agama, maka satu-satunya kepercayaan yang diterima luas hanyalah animisme itu sendiri. Sehingga adat Suku Marind dalam konteks peminangan dan walimat al-'urs ketika mengalami akulturasi dengan budaya Islam, maka adat adat dan tradisi yang bertentangan dengan semangat keislaman tidak lagi dipelihara dan justru dianggap sebagai sesuatu yang tercela. Pada titik inilah terdapat perbedaan dengan Islam Suku Marind Papua dan Islam Jawa.

Sebuah analisis penelitian dalam pelaksanaan tradisi peminangan dan walimat al-urs Suku Marind Papua di Kabupaten Merauke, sebuah agama pribumi

\footnotetext{
${ }^{15}$ Q.S Al - Baqarah (2) : (170)

${ }_{16}$ William A. Havilland, Antropologi Edisi Keempat ( jilid 2 ) diterjemahkan R.G.Soekadijo, ( Jakarta: Erlangga, 1993) hlm. 219

17 Umi Sumbulah, "Islam Jawa dan akulturasi Budaya: Karakteristik, Variasi dan Ketaatan Ekspresif", Jurnal Budaya Islam el Harakah, Vol. 14, No.1 (2012), hlm. 51 - 68.
} 
yang masih melekat dalam tradisi turun temurun Suku Marind. Agama pribumi yang sekarang dikuasai oleh Nasrani dalam Misi agama tahun 1902 silam, yang memiliki ritus-ritus yang berkaitan dengan penyembahan roh nenek moyang serta percaya terhadap kegiatan rutinitas nenek moyang mereka terdahulu. Kemudian agama Islam datang sebagai Individu-individu dari kebudayaan asing bagi mereka. Budaya Islam yang datang membawa ketaatan tata tertib kehidupan melalui Syari'ah, ketaatan melakukan shalat dalam lima waktu, kepekaan terhadap mana yang baik dan mana yang jahat dan melakukan yang baik dan menjauhi yang jahat yang berdampak pada pertumbuhan akhlak yang mulia. Jadi, dapat disimpulkan bahwa kajian akulturasi budaya tentang individu kebudayaan asing yang membawa unsurunsur kebudayaan asing adalah kebudayaan tradisi yang bertentangan dengan agama Islam khusunya syariat harus ditinggalkan dan hanya adat yang tidak menjadi aturan pokok dalam agama yang tetap dijalankan.

4. Saluran-saluran yang dilalui oleh unsur-unsur kebudayaan asing untuk masuk kedalam kebudayaan penerima. Masalah tersebut akan memberi suatu gambaran yang konkret tentang jalanya proses akulturasi antara kebudayaan.

Sujarwa dalam bukunya "Manusia dan Fenomena Budaya Menuju Perspektif Moralitas Agama" mengatakan saluran-saluran yang masuk dalam budaya penerima banyak unsurnya. Pertama, berhubungan dengan tempat-tempat keramat misalnya: makam, candi, pura, kuil, gereja, langgar, surau, masjid dan sebagainya. Kedua, aspek yang berhubungan dengan saat-saat beribadah, hari-hari keramat/suci, dan sebagainya. Ketiga, benda-benda yang dipakai dalam tradisi ritualnya termasuk patung-patung yang melambangkan dewa-dewa, alat bunyi-bunyian seperti: lonceng suci, genderang suci, dan sebagainya. Keempat, pelaku upacara keagamaan, yaitu: para pendeta biksu, syaman, kiyai, dukun, dan lain-lain. ${ }^{18}$

Peneliti menganalisis dari bukunya Sujarwa dari hasil pengumpulan data bahwa, martabat Muslim Suku Marind Papua di Kabupaten Merauke ditentukan oleh perilaku budaya orang Suku Marind pada awalnya. Perilaku budaya ini tertuang dalam tradisi peminangan dan walimat al-'urs mulai dari sikap beragama, sesesaji/seserahan, berkorban, berdoa, makan bersama dengan makanan yang telah disucikan, menari tarian suci, manyayi nyayian suci, berprosesi atau berpawai dan memainkan seni drama suci. Di antara unsur-unsur saluran tersebut ada yang dianggap penting sekali dalam satu agama, tetapi tidak dikenal dalam agama lain, dan demikian sebaliknya.

Hal ini tampak dari model pakaian yang dipakai dalam tradisi peminangan dan walimat al-'urs Muslim Suku Marind Papua yang dipakai. Dalam pemakaian pakaian masih adanya pengaruh budaya tradisonal asli suku Marind, sudah ada pengaruh wujud realitas perkembangan zaman modernisasi yaitu budaya Islam dengan budaya dari suku nenek moyang. Namun, bagi mereka sendiri tidak melunturkan nilai-nilai budaya asli yang sudah dilakukan secara turun-temurun.

5. Bagian-bagian dari masyarakat penerima yang terkena pengaruh unsur-unsur kebudayaan asing dan reaksi para individu yang terkena unsur-unsur kebudayaan

${ }^{18}$ Sujarwa, Manusia dan Fenomena Budaya Menuju Perspektif Moralitas Agama, ( Yogyakarta: Pustaka Pelajar, 1999 ) hlm.44 
asing. Proses ini dimana bagian tersebut merupakan golongan yang mendapat pengaruh dari beberapa unsur kebudayaan tertentu, sedang golongan lain bisa mendapat pengaruh dari unsur-unsur lain dari kebudayaan asing tadi. Ada kalanya yang terkena itu hanya lapisan atasan saja, rakyat jelata saja, kaum cendikiawan saja dan sebagainya. ${ }^{19}$

Ketinggalan zaman dan Kuno adalah istilah yang cocok dalam kebanyakan masyarakat industri yang maju. Kalau orang memperhatikan definisi ini lebih seksama, orang dapat melihat ini berarti tetang modernisasi yang menggambarkan perubahan sosial bagi setiap individu. Dalam hal ini ada anggapan bahwa individu masyarakat mencoba mencari kebudayaan yang lebih modern, dengan menghilangkan kebudayaan yang tradisional.

Peneliti hanya melihat dalam kasus akulturasi, unsur-unsur komponen kelompok masyarakat Suku Marind Papua, dalam kebudayaan asing yang mereka sulit diterima adalah unsur budaya yang sukar disesuaikan dengan kondisi masyarakat. Misalnya, kepala suku dalam hal ini pemimpin masyarakat Suku Marind akan sangat sulit menerima budaya baru dibandingkan dengan masyarakat biasa. Kemudian juga masyarakat yang ekonominya relatif tinggi akan sangat sulit merubah budayanya dibandingkan masyarakat yang ekonominya rendah. Dalam penelitian ini juga melihat masih adanya intervensi terhadap golongan yang menerima kebudayaan asing (budaya Islam) dari pihak-pihak masyarakat penerima sebelum proses akulturasi (budaya adat Suku Marind). Golongan penerima sebelum akulturasi ini butuh waktu berlahan-lahan untuk penyesuaian beradaptasi dengan budaya baru.

Dalam masalah akulturasi diferensial kita mempelajari tentang psikologi dalam suatu proses akulturasi. Karena, perbedaan kepribadian individu-individu penerima sebelum proses akulturasi mempengaruhi terhadap golongan yang mendapat pengaruh dari unsur-unsur lain dari kebudayaan asing tadi. Masalah reaksi orang-orang yang terkena pengaruh kebudayaan asing adalah individu yang berwatak "kolot" yang tidak suka dan lekas menolak hal-hal baru, sedangkan banyak pula individu lain yang "progresif" suka dan menerima hal baru.

Penelitian ini mencoba menganalisis tentang psikologi akulturasi diatas. Bahwa, Kepala Adat/Suku Marind dalam hal ini individu masyarakat yang sudah mempunyai kedudukan dalam masyarakat sebagai individu watak "kolot" akibat kepribadiannya yang sangat dekat dengan adatnya terdahulu dan sebagai panutan oleh masyarakat asli Suku Marind dan Suku Marind Muslim di Kabupaten Merauke. Kemudian individu yang masih adanya intervensi dari keluarga atau kebanyakan keluarganya masih berbaur dengan budaya penerima sebelum akulturasi berlangsung sebagai individu watak "kolot". Sedangkan individu-individu masyarakat Suku Marind kelas biasa, yaitu individu yang belum atau tidak mempunyai kedudukan dan masyarakat yang ekonomi tergolong rendah adalah individu dengan watak "progresif".

Pakar ahli Antropologi seperti Redfield menggunakan istilah-istilah berikut untuk menguraikan apa yang terjadi dalam akulturasi. Sesuai kajian proses akulturasi yang dikemukan menguraikan apa yang terjadi dalam proses akulturasi Masyarakat Suku Marind Papua.. Peneliti mencoba menganalisis tradisi peminangan dan walimat al-

${ }^{19}$ Koentjaraningrat, Pengantar Ilmu Antropologi, cet.10, ( Jakarta: RINEKA CIPTA, 2015 ) hlm.208 
'urs yang dilakukan oleh masyarakat Muslim Suku Marind Papua di Kabupaten Merauke dalam masalah proses akulturasi tersebut.

1. Subtitusi, Riedfield memberikan contoh proses dalam kajiannya adalah para petani mengganti alat membajak sawah oleh mesin pembajak seperti traktor. Penelitian ini membuktikan bahwa proses akulturasi ini terjadi dalam budaya Muslim Suku Marind Papua ini. Yaitu, ada pergantian budaya tradisional oleh budaya modern, kemudian tradisi-tradisi yang di larang oleh syariat Islam mereka ganti dengan tradisi-tradisi yang dibolehkan dalam Islam. Contoh: makanan, seserahan berupa barang-barang yang haram diganti dengan yang halal.

2. Sinkretisme, dalam proses akulturasi yaitu unsur-unsur budaya lama yang berfungsi padu dengan unsur-unsur budaya yang baru sehingga membentuk sistem baru. Dalam penelitian ini mengkaji proses akulturasi tersebut, yaitu: sebagian contoh dalam berpakaian tradisi lama sebelum proses akulturasi berlangsung selalu menggunkan pakaian adat suku Marind yaitu Koteka dan Rok Rumbai yang memperlihatkan keterbukaan dan ditambahi dengan pernak pernik atau aksesoris khas Suku mereka, setelah mengenal budaya baru mereka mencoba memodifikasi pakaian mereka dengan dua budaya mereka. Yaitu, Pakaian yang tertutup dengan menggunakan aksesoris atau simbol-simbol budaya lama.

3. Adisi, proses ini mencoba mendiskripsikan unsur budaya lama yang masih berfungsi ditambah unsur baru sehingga memberikan nilai lebih. Proses akulturasi ini terjadi juga dalam tradisi peminangan dan walìmat al-'urs Muslim Suku Marind Papua di Kabupaten Merauke. Hasil penelitian ini melihat dalam seserahan barang dalam peminangan. Muslim Suku Marind ini mencoba menambahkan seserahan yang dilakukan tradisi mahar dalam Islam, yaitu seperangkat alat sholat, pakaian muslim dan Kitab suci Al-Quran. Sedangkan tambahan sesarahan budaya lama seperti menyerahkan hasil kebun, pakaian adat bahkan tanaman wati.

4. Dekulturasi atau Penggantian, proses dimana budaya lama hilang karena diganti oleh unsur baru. Dalam penelitian ini menemukan unsur-unsur dalam proses akulturasi tersebut. Yaitu, dalam budaya sebelum proses akulturasi berlangsung dikenal dengan melestarikan budaya-budaya tradisional, namun peneliti menemukan masyarakat yang menghilangkan tradisi-tradisi budaya tradisonal tersebut. Tradisitradisi itu hilang yang kemudian muncul tradisi modern. Contoh lain yaitu budaya dalam pesta perkawinan masyarakat Suku Marind dalam prosesi tata ruang tempat para tamu yang mengedepankan duduk bersama dan beralaskan terpal seperti musyawarah atau FDG (Forum Discusion Group) ada yang hilang dalam tradisi ini setelah mereka beradaptasi dengan budaya baru, dan sebagian kecil seperti pemberian uang susu, dan bakar batu.

5. Orijinasi, proses merupakan unsur budaya baru yang sebelumnya tidak dikenal menimbulkan perubahan besar dalam kehidupan masyarakatnya. Dalam proses akulturasi muslim Suku Marind ini yaitu tradisi-tradisi atau unsur baru untuk memenuhi kebutuhan-kebutuhan baru yang timbul karena perubahan situasi. Proses yang dimaksud adalah tradisi pembacaan ayat-ayat suci Al-quran, pembacaan yasin tahlil sebagai pengganti tradisi bakar batu dan budaya Islam sendiri yang mengenalkan dengan kesederhanaan (adat kebiasaan tidak harus dilaksanakan). 
Atas dasar itulah perubahan - perubahan besar dapat terjadi yaitu mengislamisasikan dan dakwah Islam serta mengubah gaya hidup masyarakat tersebut.

6. Penolakan, proses akulturasi ini akibat adanya proses perubahan sosial budaya yang begitu cepat menimbulkan dampak negatif berupa penolakan dari sebagian anggota masyarakat yang tidak siap dan tidak setuju terhadap proses percampuran tersebut. Salah satu contoh dalam kehidupan zaman sekarang masih ada sebagian orang yang menolak berobat kedokter dan lebih percaya kedukun. Adat Suku Marind Papua dalam tradisinya tidak mengenal istilah penolakan. Istilah penolakan dalam akulturasi adalah perubahan-perubahan dapat begitu cepat, sehingga sejumlah besar orang tidak dapat menerimanya, yang menyebabkan penolakan total. Timbulnya pemberontakan, atau gerakan kebangkitan. Karena, peneliti melihat dalam proses akulturasi masyarakat Suku Marind tidak terjadi konflik pertemuannya dengan budaya baru. Butuh proses waktu yang lama dalam beradaptasi dengan budaya baru (budaya Islam). Karena dalam kenyataannya dalam kehidupan masyarakat musyawarah sebagai alat komunikasi dalam memilih tradisi mana yang akan digunakan.

Penelitian ini menunjukan ada proses akulturasi sehingga Islam dan adat secara berdampingan dapat menjadi nilai tunggal. Keberlangsungan ini wujud dalam konteks kesadaran untuk menerima ide dan keyakinan yang berasal dari luar kebudayaan yang sudah ada sebelumnya. Proses yang terjadi adalah menempatkan syar'a sebagai bagian dari Tradisi peminangan dan walimat al-'urs adat Marind, masyarakat yang mempunyai watak sukar berubah dan masyarakat yang mudah berubah, kemudian masyarakat dalam aspek ekonomi yaitu ekonomi rendah dan ekonomi relatif tinggi. Praktik Islam seperti hal-hal yang dianjurkan dalam budaya Islam sudah melalui proes dialog bukan dalam waktu singkat. Ini merupakan penerimaan dengan memperhatikan keberadaan pandangan Islam sebagai adaptasi dari nilai yang terbentuk atas pertemuan dua budaya.

\section{Kesimpulan}

Muslim Suku Marind melaksanakan tradisi peminangan dan walimat al-'urs selalu mengedepankan proses musyawarah sebelum tradisi ini dilangsungkan. Dalam pelaksanaanya tradisi peminangan dan walimmat al-'urs masyarakat Muslim Suku Marind Papua Kabupaten Merauke ada 3 macam yaitu: tradisi tradisional (masa lalu) karena menghargai tradisi adat Marind dan akibat Islam minoritas dalam keluarga, tradisi percampuran antara kedua budaya, tradisi yang menghilangkan tradisi adat Marind ( Modern ).

Secara umum agama Islam yang telah hidup ditengah-tengah masyarakat Muslim Suku Marind Papua menghasilkan sebuah paradigma perubahan pada diri mereka. Hal tersebut ini membawa dampak terhadap perubahan tradisi dalam perkawinan. Mulai dari tradisi budaya lokal suku Marind sampai perilaku mereka terhadap tradisi mulai hilang. Namun, proses perubahan budaya atau tradisi asli mereka dan perpindahan keyakinan, tidak mempengaruhi adanya konflik. Justru yang terjadi adalah perpaduan yang saling menguntungkan. Islam dijadikan sebagai bagian dari identitas sosial untuk memperkuat identitas yang sudah ada sebelumnya. Hal ini 
memberikan sebuah arti khusus terhadap orang Suku Marind Papua, bahwa orang Suku Marind Papua terbuka terhadap Budaya baru.

Akulturasi budaya ini merupakan teori yang mengansumsikan bahwa ada pertemuan dua budaya, antara budaya lokal dengan budaya baru yang mengahasilkan saling terjadinya kontak dan adaptasi dengan budaya. Dalam uraian teori tersebut tradisi lokal ini adalah tradisi yang sudah dilakukan Suku Marind Papua di Kabupaten Merauke sejak nenek moyang mereka dengan tradisi Islam berkeyakinan dalam diri mereka. Dari sudut pandang teori ini terjadilah suatu proses akulturasi, yaitu perubahan-perubahan tradisi. Dalam penelitian ini, peneliti tidak menemukan penolakan dalam proses akulturasi karena, sudah terjadi proses musyawarah dalam melakukan sebuah tradisi baru. Akulturasi Riedfild ini juga tidak pernah menyinggung adanya musyawarah dalam melakukan perubahan budaya.

Berdasarkan hasil analisa dan kesimpulan sebagaimana dipaparkan diatas maka ada beberapa hal yang harus ditindaklanjuti baik bagi peneliti selanjutnya, masyarakat secara umum, serta pemerintah setempat beserta stakehalders, antara lain: Bagi peneliti selanjutnya hendaklah melakukan penelitian lebih mendalam tentang Suku Marind Papua di Kabupaten Merauke. Karena, peneliti ini dilakukan dalam kontek tradisi pernikahan mereka. sehingga belum bisa memberikan gambaran yang mendalam tentang asal-usul Suku Marind ini. Agar peneliti bisa lebih objektif dan jelas serta untuk tujuan kehidupan yang lebih baik bagi masyarakat Suku Marind.

\section{Refrensi}

Ali, Aryanto, Dokumen Materi Kuliah: Etnografi Papua, (Merauke: Sekolah Tinggi Agama Islam (STAIS) Yamra Merauke, 2009

Arikunto, Suharsimi Prosedur Penelitian: Suatu Pendekatan Praktik, Jakarta: Bineka Cipta, 2010

Hadikusuma, Hilman Hukum Perkawinan Indonesia Menurut; perundangan, Hukum Adat, Hukum Agama, Bandung: CV.Mandar Maju, 2007

Hindi, Ardiun,Tradisi Bergubalan Dalam Perkawinan Masyarakat Muara Enim Sumatera Selatan Menurut Perspektif Islam, Fakultas Syari'ah UIN Maliki Malang, Jurnal Hukum dan Syari'ah, Volume 1, No.1, 2010

Kasiran, Moh, Metodologi Penelitian: Refleksi Pengembangan Pemahaman dan Penguasaan Metode Penelitian, Malang: UIN Press, 2010

Koentjaraningrat, Pengantar Ilmu Antropologi, cet.10, Jakarta: RINEKA CIPTA, 2015

Moleong, Lexy, Metodologi Penelitian Kualitatif, Bandung: Rosda Karya, 2005

Rais, Za'im, The Minangkabau Traditionalists' Response to The Modernist Movement, Disertasi, Montreal: McGill University, 1994

Shah, Sheetel.R, The Impact of Acculturation and Religion on Intergenerational Family Conflict for Second Generation Asian Indian Americans,Tesis, Carbondale: Southern Illinois University, 2006

Sujarwa, Manusia dan Fenomena Budaya Menuju Perspektif Moralitas Agama, Yogyakarta: Pustaka Pelajar, 1999

Sumber Online, Merauke, Tempat Mayoritas Muslim Penduduk Papua, INTERNASNEWS, diakses 28 Juni 2017 


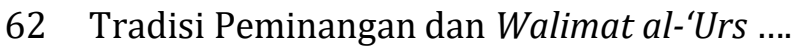

Sumbulah, Umi, "Islam Jawa dan akulturasi Budaya: Karakteristik, Variasi dan Ketaatan Ekspresif", Jurnal Budaya Islam el Harakah, Vol. 14, No.1 2012

Sztompka, PiÖtr, Sosiologi Perubahan Sosial, Terj.Alimandan), Jakarta: Prenada Media Grup, 2007

William A. Havilland, Antropologi Edisi Keempat ( jilid 2 ) diterjemahkan R.G.Soekadijo, Jakarta: Erlangga, 1993 